\title{
Four-Week Fluoxetine (SSRI) Exposure Diminishes Aggressive Behaviour of Male Siamese Fighting Fish (Betta splendens)
}

\author{
Bogdan F. Kania, Mikołaj A. Gralak, Malgorzata Wielgosz \\ Department of Physiological Sciences, Faculty of Veterinary Medicine, Warsaw University of Life Sciences-SGGW, \\ Warsaw, Poland \\ Email: \{mikolaj_gralak, bogdan_kania\}@sggw.pl
}

Received August 12, 2011; revised August 26, 2011; accepted September 6, 2011

\begin{abstract}
Aggression, especially territorial is a serious problem in farmed and ornamental fish. Especially the tropical species like Siamese fighting fish Betta splendens or marine species like blu head Thalassoma bifasciatum. Also farmed species of Salmoniformes (Coho salmon Oncorhynchus kisutch, rainbow trout Oncorhynchus mykiss) exhibit territorial aggression which is correlated with growth rate of the fish. In these species native territorial aggression occurs, and in ethology it is called stereotypical agonistic behaviour or conspecific aggression. In this type modulation of aggression serotonin (5-HT) plays a main role. A decrease of 5-HT in brain intensifies these type of aggression and in opposite an increase of 5-HT reduces it. The purpose of this study was to examine the effects of different doses of fluoxetine on male aggressive behaviors of Betta splendens fish. It was concluded that fluoxetine added to aquarium water in the doses of 4,40 and/or $100 \mu \mathrm{g} \cdot \mathrm{g}^{-1}$ BW during 14 - 28 days increased synaptic levels of 5-HT what in turn resulted in the reduction of the specific aggressive behaviors. Fluoxetine caused periodic, and sometimes even total weakening of male-male type fight, which is a standard trial applied in ethological research on Siamese fighting fish. In current study, the most effective was the dose of $40 \mu \mathrm{g} \cdot \mathrm{g}^{-1} \mathrm{BW}$. The mechanism of this antiaggressivity depended on an increase of serotonergic system activity in animal brain (especially, in raphe nuclei), however synaptic levels of 5-HT in brain were not measured in this experiment. Thus, the hypothesis that exposure from day $1-21$ would reduce aggression was rejected; as was the hypothesis that exposure on fluoxetine from day 10 (16) - $14-28$ would rapidly reduce aggression in teleost fishes. The results obtained suggests that a complex role of serotonin in the expression of aggression in teleost fish because acute treatment with 5-HT1A receptor agonist WAY-100635 did not increase aggression in fish [1]. We emphasize the physiological concepts that can be addressed with this experiment, including the role of the serotonergic system in regulation of aggression, and the interplay of environmental contaminants and physiology in regulating the expression of behavior of fishes.
\end{abstract}

Keywords: Betta splendens; Aggression; Fluoxetine; Chronic Dosage

\section{Introduction}

Expression of agonistic conspecific behavior over territory boundaries for example allows individuals for exclusive access to food resources, nesting sites and to mate, what is very important for both reproduction and survival. Territorial aggression may be expressed in variable forms, including vigilance and patrolling behavior, exhibition of stereotyped displays, vocalizations, chasing intruders, and engaging in physical combat [2].

Siamese fighting fish - Betta splendens has been an useful model species since 25 years, for the study the mechanism of territorial aggression is throughout the vertebrate classes. A low cost and ease of its maintaining in the studies on aggressive behavior in the laboratory are im- portant considerations. Siamese fighting fish (hereafter referred to by the common name "betta") are found in freshwater ponds of Southeast Asia. They are also cultivated as ornamentals and are readily available in pet stores around the world. Males of this species exhibit strong and stereotyped aggression in defending their territories against intruding male conspecifics [3]. Patterns of aggression behavior include frontal displays (erecting the operculate, fins, and tail while facing opponent accompanied by erection of fins and tail), and physically attacking and biting the intruder. Males may also intensify scale coloration during an agonistic interaction [4]. The male bettas are particularly useful for investigations of aggressivity as an agonistic behavior, because-as mentioned above - aggressive behavior patterns in this 
species are easy to observe and quantify, and males exhibit high levels of conspecific aggression when presented with a mirror or an appropriate releaser of this behavior [4].

Serotonin (5-hydroxytryptamine, 5-HT) is an important neurotransmitter and/or neuromodulator as a regulator of aggressive behavior in vertebrates. Across a variety of these classes, serotonergic activity significantly increased in less aggressive males in comparison to more aggressive [5]. Experimentally increased concentrations of 5-HT or serotonergic activity has also been shown to reduce aggression in birds, other fishes, reptiles and mammals [6-10].

Fluoxetine (Prozac, Bioxetin, Biozac) belongs to the class of drug antidepressants called selective serotonin reuptake inhibitors (SSRI's), which inhibit the neuronal reuptake pump for 5-HT. Fluoxetine effectively increases levels of 5-HT at synapses in both, central and peripheral nervous systems and in this manner suppresses aggressive behavior [11,12]. Thus fluoxetine can be a useful experimental tool for detecting the action of 5-HT on target cells and the role of 5-HT in regulation of aggression in vertebrates.

It was confirmed that both acute [2] and chronic i.p. administration of fluoxetine significantly reduced the expression of aggressive behavior in a coral reef fish, the blue head wrasse (Thalassoma bifasciatum) [6]. However, Clotfelter et al. [1] presented, that i.m. chronic administration of fluoxetine did not alter the expression of aggressive behavior in male bettas. This lack of effects might be related with species-specific differences, problem of dose and/or duration or route of treatment. Injections are often a useful and reliable method of treating animals. But, injections in small fishes, present several problems in a laboratory practice. The handling and immobilization every day associated with injections can impact subsequent behavior. Moreover it can also affect the fish mucous coat, what may potentially promote infection and dead following experimentation [2]. To avoid these problems as well as to minimize immobilization stress associated with capture and handling, we have developed a technique that allows the epithelial absorption of fluoxetine in male bettas, primarily via the gills, followed by controlled testing for aggressive responses to a mirror challenge by 10 minutes. The addition of the drug to the aquarium water, in our case fluoxetine, its epithetlial absorption from the surrounding water is also important form environmental point of view. SSRI's such a fluoxetine or sertaline, for example, are the most widely prescribed antidepressants in the United States and many other countries [13]. Recent studies have confirmed that antidepressants, including fluoxetine, are discharged in municipal wastewater, treatment plant effluents, and are widespread in surface waters of United States [14,15]. Thus aquatic animals may be exposed to concentrations of SSRI's, at levels high enough to possibly alter both, their behavior and physiology. Populations of several species of fish living in a municipal effluent-dominated stream reportedly contained levels of fluoxetine (and the pharmaceuticals: ranitidine, warfarin or cimetidine, for example) at concentrations higher than $0.1 \mathrm{ng} \cdot \mathrm{g}^{-1}$ liver, brain or muscle tissues [14-16]. The epithelial absorption represents a plausible mechanism for the absorption of environmental contaminants in body tissues of animal aquatic $[17,18]$.

Assessing of the risk for humans related with the presence of pharmaceuticals in waters is of high priority. However, the impacts of these drugs on aquatic organisms and communities are also important [10]. The goal of this study was to evaluate the effects of waterborne fluoxetine on the aggressive behaviors of bettas and their correlations with 28 days exposure in different concentrations. Fishes are an excellent model for studying effects of environmental pollutants, because many ecologically relevant fish behaviors may be easily observed and quantified in controlled conditions [10]. Fluoxetine doses were tested at aquatic ecological levels $\left(4 \mu \mathrm{g} \cdot \mathrm{g}^{-1}\right)$, ten and twenty five times greater than the dose found in the environment, in order to more clearly quantify the relationship between fluoxetine-induced changes in expression of aggressive behavior and drug dose.

\section{Materials and Methods}

The procedures described below were performed with the approval of Local Ethical Commission for Care and Use of Laboratory Animals. We used sexually mature male Siamese fighting fish-Betta splendens (male betta) of the domesticated strain obtained from a local distributor (Zoomix, Warsaw, Poland). Fishes were housed individually in $2 \mathrm{~L}$ containers, kept on a 12:12 light:dark cycle and fed once daily with dried chironomid larvae. They were held at a controlled temperature of $22^{\circ} \mathrm{C}$ $24^{\circ} \mathrm{C}$ in municipal Oligocene water. The mean body mass of fishes used in this experiment was $1.66 \pm 0.02 \mathrm{~g}$. Fishes were typically housed in the laboratory for $3-4$ weeks prior to and then during 4 weeks of their participation in the experiment, and no fish was used for more than one treatment.

Following the mirror test, control fish received a 100 $\mu \mathrm{l}$ of teleost saline only, while first experimental group received $4 \mu \mathrm{g} \cdot \mathrm{g}^{-1}$ body weight (BW), second $40 \mu \mathrm{g} \cdot \mathrm{g}^{-1}$ and third $100 \mu \mathrm{g} \cdot \mathrm{g}^{-1}$ in $100 \mu \mathrm{l}$ of teleost saline, daily. Dosages listed above were calculated individually based on previous studies (on fishes, where possible) and extrapolated to an approximate body mass of $1.5 \mathrm{~g}[1,6]$.

Fluoxetine hydrochloride in substantia was purchased from Sigma-Aldrich (St. Louis, USA). Within an experiment, fishes typically varied in mass by less than $10 \%$. Hence, we used the same dosage of fluoxetine for indi- 
vidual fish assigned in specific treatment during 28 days. Fish were randomly assigned to treatment groups, and on $14^{\text {th }}$ day they were presented with a $25.4 \times 15 \mathrm{~cm}$ mirror for $10 \mathrm{~min}$. Fourteen days later, on the $28^{\text {th }}$ day of the experiment, we re-evaluated aggressive behavior in each fish with the following mirror test.

Mirror image stimulus tests are a standard protocol for eliciting aggression in betta. Results from mirror tests are significant predictors of reactions to other stimuli, such as videotaped or live males, as well as of dominance in dyadic interactions $[19,20]$. The duration(s) of opercula displays was recorded, because they are known to be associated with fight outcome [1]. In a subset of tests, we also measured the latency(s) to respond to the mirror. All mirror tests and all applications of drug were performed between 12 and 16 EST.

Statistical analyses were performed using the SPSS 12.0 PL for Windows statistics package (IBM, Chicago, Il, USA). To compare the average results in experimental and control groups one-way and two-way ANOVA were used and Bonferroni post-hoc test was applied when appropriate. Additionally, on account of major merits of the standard deviations from the mean values, Spearman's correlation was used. The results were considered as statistically significant at the $\mathrm{p} \leq 0.05$ and highly significant at the $\mathrm{p} \leq 0.01$.

\section{Results}

All fishes were tested in a mirror test before experiment. Then, incessantly by 28 days fluoxetine was added to the aquarium water in the dose of $4 \mu \mathrm{g}\left(\mathrm{n}=8\right.$, group $\left.\mathrm{II}^{\mathrm{nd}}\right), 40$ $\mu \mathrm{g}\left(\mathrm{n}=8\right.$, group $\left.\mathrm{III}^{\mathrm{rd}}\right)$ and $100 \mu \mathrm{g} \cdot \mathrm{g}^{-1} \mathrm{BW}$ added in 100 $\mu \mathrm{l}$ ration of water $\left(\mathrm{n}=8\right.$, group $\left.\mathrm{IV}^{\text {th }}\right)$ and $100 \mu \mathrm{l}$ of physiological saline to the control group $\left(n=8\right.$, group $\left.\mathrm{I}^{\mathrm{st}}\right)$. On the $14^{\text {th }}$ and $28^{\text {th }}$ days of the experiment mirror test were held (the mirror was placed in front of the fish in the aquarium). During the test males were displaying the evidences of aggression (ruffling fins, frontal attacks, and biting the intruder).

On the $14^{\text {th }}$ days from the beginning of the experiment there was a marked reduction of number of attacks in the $\mathrm{II}^{\text {nd }}$ group ( $\mathrm{p}>0.05$ ), from 16 to $13 / 10 \mathrm{~min}$ and in the III $^{\text {rd }}$ group $(p \leq 0.05)$ from 14 to $4 / 10 \mathrm{~min}$, while in the other groups the attack number insignificantly increased properly from 17 to $25 / 10 \mathrm{~min}$ in the control (group $\mathrm{I}^{\text {st }}$ ) and from 13 to $20 / 10 \mathrm{~min}$ in the $\mathrm{IV}^{\text {th }}$ group (Figure 1). In following days of the experiment, the number of the attacks was reduced in comparison to $14^{\text {th }}$ day. In the mirror test performed on the $28^{\text {th }}$ day these bumbers were decreased to 14 in the $\mathrm{I}^{\text {st }}, 6$ in the $\mathrm{II}^{\text {nd }}, 3$ in the III $^{\text {rd }}$ and 18 in the $\mathrm{IV}^{\text {th }}$ group, in comparison to the control values, respectively. Daily adding of the fluoxetine to aquarium water in the dose $4 \mu \mathrm{g}$ and $400 \mu \mathrm{g} \cdot \mathrm{g}^{-1} \mathrm{BW}$ did not resulted in significant changes in the number of attacks neither on the $14^{\text {th }}$ nor on $28^{\text {th }}$ day, while the dose of 40 $\mu \mathrm{g} \cdot \mathrm{g}^{-1} \mathrm{BW}$ significantly reduced it in both terms $(\mathrm{n}=8, \mathrm{p}$ $\leq 0.05)$. This reduction of the attack number in the III $^{\mathrm{rd}}$ group during four weeks of exposition to fluoxetine equaled to $80 \%$ of the initial value on the day 0 .

During two weeks of exposition to fluoxetine, the summed up time of attacks was continuously abridged in all groups. In the control group $\left(\mathrm{I}^{\text {st }}\right)$ it was shortened properly from 315 measured on 0 day, to $301 \mathrm{~s} / 10 \mathrm{~min}$. for the control group (group ${ }^{\mathrm{st}}$ ), in the $\mathrm{II}^{\text {nd }}$ group from 440 to $323 \mathrm{~s} / 10 \mathrm{~min}$., in the III $^{\text {rd }}$ group treated with 40 $\mu \mathrm{g} \cdot \mathrm{g}^{-1} \mathrm{BW}$ from 425 to $290 \mathrm{~s} / 10 \mathrm{~min}$. and from 485 to $352 \mathrm{~s} / 10 \mathrm{~min}$. in the $\mathrm{IV}^{\text {th }}$ experimental group treated with $400 \mu \mathrm{g} \cdot \mathrm{g}^{-1} \mathrm{BW}$. Till the $28^{\text {th }}$ day, the total time of attacks was still sustaining an abridgement in case of the III $^{\text {rd }}$ and $\mathrm{IV}^{\text {th }}$ groups, properly to 314 and $364 \mathrm{~s} / 10 \mathrm{~min}$, respectively (Figure 2). The analysis of variance did not show any significant influence of the dose of the drug on the duration of aggressive behavior $(n=8, p>0.5)$.

The latency time till ruffling of the fins, measured on the $14^{\text {th }}$ day of the experiment in three groups insignificantly decreased as compared to the test performance before application of drug (day 0): in the control group ( ${ }^{\text {st }}$ group) from 14 to $6 \mathrm{~s} / 10 \mathrm{~min}$, in the $\mathrm{II}^{\text {nd }}$ one from 29 to 8 , in the III $^{\text {rd }}$ one from 40 to 24 . However in the IV $^{\text {th }}$ group the latency time till ruffling the fins was extended from 11 to $29 \mathrm{~s}$. The same parameter measured on the

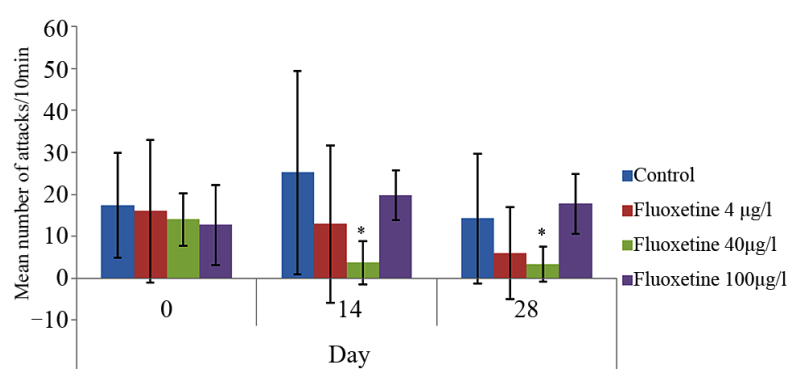

Figure 1. The influence of different doses of fluoxetine $(4,40$ and $100 \mu \mathrm{g} \cdot \mathrm{g}^{-1} \mathrm{BW}$, group $\mathrm{II}^{\text {nd }}, \mathrm{III}^{\text {rd }}$ and $\mathrm{IV}^{\text {th }}$, respectively) on average number of attacks in betta males during 10 minutes mirror test in comparison with control values (group $\mathrm{I}^{\text {st }}$ ) $(\mathbf{x} \pm \mathbf{S D}, \mathbf{n}=\mathbf{8})$.

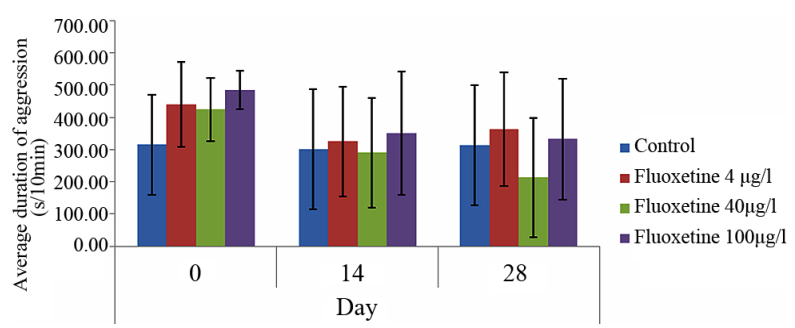

Figure 2. The influence of different doses of fluoxetine $(4,40$ and $100 \mu \mathrm{g} \cdot \mathrm{g}^{-1} \mathrm{BW}$, group $\mathrm{II}^{\text {nd }}, \mathrm{III}^{\text {rd }}$ and $\mathrm{IV}^{\text {th }}$, respectively) on summed up time attacks in betta males during 10 minutes mirror test in comparison to the control values (group $\left.I^{\text {st }}\right)(\mathbf{x} \pm \mathbf{S D}, \mathbf{n}=\mathbf{8})$. 
$28^{\text {th }}$ day of the experiment did not changed significantly with the exception of the III ${ }^{\text {rd }}$ group in which the latency time was prolonged $(\mathrm{p} \leq 0.05)$ by additional $94 \mathrm{~s}$ (Figure 3).

Daily adding of the fluoxetine to aquarium water in the dose of $4 \mu \mathrm{g}$ and $400 \mu \mathrm{g} \cdot \mathrm{g}^{-1} \mathrm{BW}$ did not resulted in significant changes in the number of attacks neither on the $14^{\text {th }}$ nor on $28^{\text {th }}$ day, while the dose of $40 \mu \mathrm{g} \cdot \mathrm{g}^{-1} \mathrm{BW}$ significantly reduced it in both terms $(n=8, p \leq 0.05)$. This reduction of the attack number in the III $^{\text {rd }}$ group during four weeks of exposition to fluoxetine equaled to $80 \%$ of the initial value on the day 0 .

The analysis of variance did not show any significant influence of the dose of the drug on the duration of aggressive behavior $(n=8, p>0.5)$.

Although results showed at the Figures 1-3 varied much, only the III ${ }^{\text {rd }}$ group differed significantly from the control one in the number of attacks as well as in the latency time to the aggressive behavior. This derives from very high individual variation of the examined fishes, what implicated major values of standard deviations. In order to the more precise display of the influence of the dose and time on the fish behavior, Spearman's correlation was decided to examine. The correlation showed a significant influence of the duration of drug application on the aggressive behavior number ( $\mathrm{p} \leq 0.05)$, on the duration of aggressiveness time $(p \leq 0.05)$ and highly significant influence of the dose on the latency time till the fins ruffling $(\mathrm{p} \leq 0.01)$.

\section{Discussion}

Female betta fish chooses a male that is the most aggressive because he most probably may be the best protector of her and her eggs. The male of this species is useful model in the study of aggression, because their different degrees of the agonistic conspecifics stereotyped behaveior towards one another [21].

In the study we administered 4, 40 and/or $100 \mu \mathrm{g}$ fluoxetine per $\mathrm{g} \mathrm{BW}$ of betta male fish what equaled to the following fluoxetine concentration in water $( \pm 2-3$,

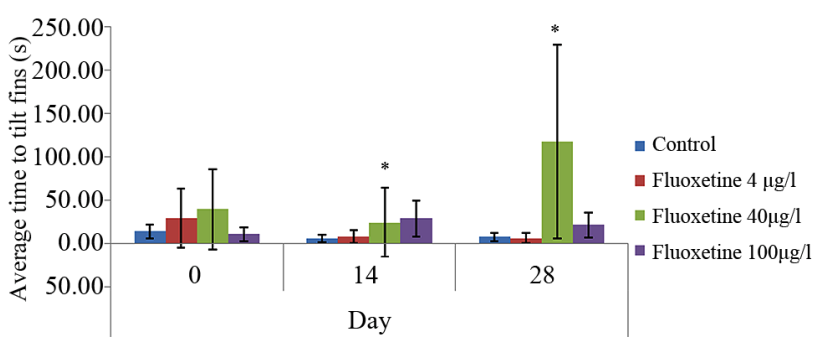

Figure 3. The influence of different doses of fluoxetine $(4,40$

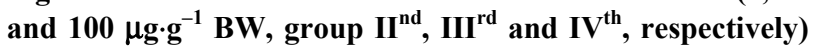
on mean time till the ruffling of fins in betta during mirror test in comparison with control values (group $\left.I^{\text {st }}\right)(x \pm S D, n$ $=8)$.
20 - 30, or 50 - $75 \mu \mathrm{g} \cdot \mathrm{L}^{-1}$, respectively) which was added every day via aquarium $2 \mathrm{~L}$ water. We have demonstrated that 28-day exposure to above doses of fluoxetine significantly altered the expression of aggressive behaveior in male bettas in laboratory conditions. Especially, when fishes were treated with fluoxetine, number of attacks was reduced (the number of brad side displays and $90^{\circ}$ turns) during $10 \mathrm{~min}$ of the mirror test and the total average summed up time of these attacks had a tendency to be reduced was diminished in comparison to the control values. The differences were not significant because of very high individual variation of the examined fishes, what implicated major values of standard deviations. Although results showed at the Figures 1-3 varied much, only $\mathrm{III}^{\text {rd }}$ group $\left(40 \mu \mathrm{g} \cdot \mathrm{g}^{-1} \mathrm{BW}\right)$ differed significantly from the control one in the number of attacks. The efficiency of this dose was even better pronounced in the latency time to the aggressive behavior (ruffing of fins). We observed significantly $(\mathrm{p} \leq 0.05)$ longer lag time in this group as compared to all other groups. Similar observations were published by Lynn et al. [2]. He demonstrated that after a $3-\mathrm{h}$ exposure to $3 \mu \mathrm{g} \cdot \mathrm{ml}^{-1}$ (i.e. 3000 $\left.\mu \mathrm{g} \cdot \mathrm{L}^{-1}\right)$ fluoxetine administered via aquarium water significantly inhibited the expression of aggressive behavior in male bettas. The doses administered by those authors, however, were 40 - 1500 times higher ones administered in his study, and have been considered as a subtoxic ones. To the authors' knowledge there are no data available with regards to the explanation why in this experiment the highest dose of fluoxetine applied $\left(100 \mu \mathrm{g} \cdot \mathrm{g}^{-1} \mathrm{BW}\right)$ was less effective than the dose of $40 \mu \mathrm{g} \cdot \mathrm{g}^{-1} \mathrm{BW}$.

Parsons [21], in turn, administering $0.54 \mu \mathrm{g} \cdot \mathrm{L}^{-1}$ of fluoxetine (realistic environmental concentrations) to five male bettas during 5 consecutive days, because earlier Kolpin et al. [14] concluded that above mentioned concentrations of drug were detected in several species of fish living in municipal effluent-dominated streams and storm water canals. Hereafter, authors cited above, increased administered dose of fluoxetine to $162 \mu \mathrm{g} \cdot \mathrm{L}^{-1}$ for 5 consecutive days, also. During antiaggressive influence of the drug, the tested fishes were removed from the $2 \mathrm{~L}$ treatment containers using a small dip net and were quickly placed in their $13.5 \mathrm{~L}$ home thanks. Fishes were then allowed $15 \mathrm{~min}$ to acclimate to their home big thanks and then tested during $5 \mathrm{~min}$ in mirror test. Fishes after termination of the testing period were transported de novo to small containers. It was concluded that the compared to the control fish, the treated fish reduced aggressive actions only after 4-day exposure. Towards to the end $\left(11^{\text {th }}\right.$ day) of the experiment the control fish began to reduce their aggression (by 50\%) [21]. It is possible the fish were learning or adapting to the larger thank during deplacing for the mirror test by $5 \mathrm{~min}$ every day. Learning allows the fish to conserve energy [22]. During 
the experiment some of the fish wound position themselves horizontally to the mirror and make certain movements to try determine if there was another fish beside of them. These data indicated that so called environmental concentrations of fluoxetine $\left(0.54 \mu \mathrm{g} \cdot \mathrm{L}^{-1}\right)$ can diminish aggressivity of adult males of Betta splenedens. These data confirmed the study of Perrault et al. [6] who tested fluoxetine on aggressive coral reef fish. All the observations cited above suggests that fluoxetine exposure affects behaviors of aquatic organisms. This reduced aggression could impact on the reproductive output of Betta splendens males [21] and could trouble ecosystem of aquatic animals. These so called environmental concentrations of fluoxetine in water were also detected by McGrudy [16]. He stated, according to the Center for Disease Control and Prevention, that in 2002 approximately 245 millions of Americans administered pharmaceutical products themselves daily. Therefore, the largest contribution to the quantity of pharmaceuticals in the environment is the excretion from humans by feces and urine [23]. Among them approximately 50 million people today take antidepressants, mainly fluoxetine (www. prozac.com). Brooks et al. $[15,24]$ presented, that when tissues of fish living in effluent-dominated streams were extracted and analysed using gas chromatography-mass spectrometry, the antidepressant drugs: fluoxetine and norfluoxetine - its principal active metabolite-were detected at concentrations greater than $0.1 \mathrm{ng} \cdot \mathrm{g}^{-1} \mathrm{BW}$. The average concentration of these drugs in 84 streams in United States was $0.18 \mu \mathrm{g} \cdot \mathrm{L}^{-1}$; average recovery $\leq 60 \%$ [16].

An unexpected interesting fact was that the control fish decreased their aggression over half by the eleventh day compared to the fourth day from exposure [21]. It is possible the fish were learning or adapting to the larger tank during deplacing for the mirror test by $5 \mathrm{~min}$ every day. Learning allows the fish to conserve energy [22]. During the experiment some of the fish would position themselves horizontally to the mirror and make certain movements to try determine if there was another fish beside of them.

It seems that relatively short-term exposure (3 or $6 \mathrm{~h}$ ) of male bettas to as little as 3 and $6 \mu \mathrm{g} \cdot \mathrm{mL}^{-1}$ of fluoxetine (i.e. 3 and $6 \mathrm{mg} \cdot \mathrm{L}^{-1}$, respectively) added to aquarium water is not sufficient to significantly reduce the expression of conspecific aggressive behaviors as a contested by Lynn et al. [2]. In humans the peak plasma concentrations of this drug occurs in six to eight hours after swallowing regular capsules and tablets [21]. Fluoxetine-as mentioned above-is selective serotonin reuptake inhibitor in serotonergic cerebral structures, particularly in Raphe nuclei. It reveals the longest half-life of all SSRI's (selective serotonin reuptake inhibitors) and therefore enhances the action of the 5-HT, due to highly specific se- rotonin reuptake blockade at presynaptic neural membrane. The dopamine transporter is weakly inhibited by fluoxetine. When 5-HT levels are lower in vertebrates, the males are more aggressive [6]. Fluoxetine's principal metabolite, norfluoxetine and steady-state concentration of fluoxetine in plasma occur in two to four weeks, at least in humans. It can readily cross the blood/brain barrier, placenta and breast/milk [21]. It is not possible that epithelial absorption of fluoxetine in betta males was so dramatically efficient during $3 \mathrm{~h}$ after addition of the drug to aquarium water, and that was why it could not reduce significantly the expression of aggressive behaveiors in some experiments. McCrudy [16] concluded that an exposure to fluoxetine from day 1 - 21 would cause rapid aggression reduction compared to control bettas only after the 10-day application of the drug. In our study, in order to the more precise display of the influence of the dose and time on the fish behavior, the regression analysis was decided to performed. The correlation (Spearman's) showed a significant influence of the duration of drug application on the aggressive behavior number $(\mathrm{p} \leq$ 0.05 ) and highly significant influence of the dose on the latency time till the fins ruffling $(\mathrm{p} \leq 0.01)$.

In summary, results of this study suggest that fluoxetine administered via aquarium water significantly inhibits the expression of aggressive behavior in male Siamese fighting fish (Betta splendens). However there is a huge individual variability between males in the reaction to the fluoxetine administration.

\section{REFERENCES}

[1] E. D. Clotfelter, E. P. O'Hare, M. H. Mc Nitt, R. E. Carpenter and C. H. Summers, "Serotonin Decreases Aggression via 5-HT1A Receptors in the Fighting Fish," Betta splendens, Pharmacology, Biochemiistry and Behaviour, Vol. 87, No. 2, 2007, pp. 222-231.

[2] S. H. Lynn, J. M. Egar, B. G. Walker, T. S. Sperry and M. Ramenovsky, "Fish on Prozac: A Simple, Noninvasive Physiology Laboratory Investigating the Mechanisms of Aggressive Behavior in Betta splendens," Advances in Physiological Education, Vol. 31, No. 4, 2007, pp. 358363. doi:10.1152/advan.00024.2007

[3] M. Jaroensutasinee and K. Jaroensutasinee, "Sexual Size Dimorphism and Male Contest in Wild Siamese Fighting Fish," Journal in Fish Biology, Vol. 59, No. 6, 2001, pp. 1614-1621. doi:10.1111/j.1095-8649.2001.tb00225.x

[4] M. A. Abate, "Using a Popular Pet Fish Species to Study Territorial Behaviour," Journal in Biology of Education Vol. 39, No. 2, 2005, pp. 81-86. doi:10.1080/00219266.2005.9655967

[5] J. M. Matter, P. J. Ronan and C. H. Summers, "Central Monoamines in Free-Ranging Lizards: Differences Associated with Social Roles and Territoriality," Brain Behavioural Evolution, Vol. 51, 1998, pp. 23-32.

[6] H. A. N. Perreault, K. Semsar and J. Godwin, "Fluoxetine 
Treatment Decreases Territorial Aggression in a Coral Reef Fish," Physiology Behaviour, Vol. 79, No. 4-5, 2003, pp. 719-724. doi:10.1016/S0031-9384(03)00211-7

[7] T. S. Sperry, C. K. Thompson and J. C. Wingfield, "Effects of Acute Treatment with 8-OH-DPAT and Fluoxetine on Aggressive Behaviour in Male Song Sparrows (Melospiza melodia morphana)," Journal Neuroendocrinology, Vol. 15, No. 2, 2003, pp. 150-160. doi:10.1046/j.1365-2826.2003.00968.x

[8] T. S. Sperry, I. T. Moore, S. L. Meddle, A. M. Benovitz-Fredricks and J. C. Wingfield, "Increased Sensitivity of the Serotonergic System during the Breeding Season in Free-Living American Tree Soarrows," Behavioural Brain Research, Vol. 157, No. 1, 2005, pp. 119-126. doi:10.1016/j.bbr.2004.06.015

[9] E. D. Clotfelter and A. Paolino, "Bystanders to Contests between Conspecifics Are Primed for Increased Aggression in Male Fighting Fish," Animal Behaviour, Vol. 66, No. 2, 2003, pp. 343-347. doi:10.1006/anbe.2003.2227

[10] K. M. Gaworecki and S. J. Klaine, "Behavioral and Biochemical Responses of Hybrid Striped Bass during and after Fluoxetine Exposure," Aquatic Toxicology, Vol. 88, No. 4, 2008, pp. 207-213. doi:10.1016/j.aquatox.2008.04.011

[11] I. Malagie, A. C. Trillat, C. Jacquiot and A. M. Gardier, "Effects of Acute Fluoxetine on Extracellular Serotonin Levels in the Raphe; an in Vitro Microdialysis Study," European Journal of Pharmacology, Vol. 286, No. 2, 1995, pp. 213-217. doi:10.1016/0014-2999(95)00573-4

[12] C. Sanchez, "Interaction Studies of 5-HT1A Receptor Antagonists and Selective 5-HT Reuptake Inhibitors in Isolated Aggressive Mice," European Journal of Pharmacology, Vol. 334, No. 2-3, 1997, pp. 127-132. doi:10.1016/S0014-2999(97)01199-0

[13] A. J. Gelenberg and H. S. Hopkins, "Assessing and Treating Depression in Primary Care Medicine," American Journal of Medicine, Vol. 120, No. 2, 2007, pp. 105-108. doi:10.1016/j.amjmed.2006.05.059

[14] D. W. Kolpin, E. T. Furlong, M. T. Meyer, E. M. Thurman, S. D. Zaugg, L. B. Barber and H. T. Buxton, "Pharmaceuticals, Hormones, and Other Organic Wastewater Contaminants in the US Streams, 1999-2000: A National Reconnaissance," Environmental Science and Technology, Vol. 36, No. 6, 2002, pp. 1202-1211. doi:10.1021/es011055j

[15] B. W. Brooks, C. K. Chambliss, J. K. Stanley, A. Ramirez, K. E. Banks and R. D. Johnson, "Determination of
Select Antidepressants in Fish from an Effluent-Dominated Stream," Environmental Toxicology and Chemistry, Vol. 24, No. 2, 2005, pp. 464-469. doi:10.1897/04-081R.1

[16] W. Y. McCrudy, “The Influence of Staggered Exposure to Fluoxetine on Aggressive Behaviors in Siamese Fighting Fish (Betta splendens)," A Report of a Senior Study, Maryville College Fall, 2006, p. 14.

[17] S. Foberg, "The Siamese Fighting Fish (Betta splendens) - An Alternative Fish Species to Use in Evaluating Impact of Endocrine Disrupting Chemicals with Focus on Aggressive Performance (Thesis)," Uppsala University, Uppsala, 2003.

[18] C. M. Foran, J. Weston, M. Slattery, B. W. Brooks and D. B. Hugget, "Reproducive Assessment of Japanese Medaka (Oryzias latipes) Following a Four-Week Fluoxetine (SSRI) Exposure," Archives of Environmental Contamination and Toxicology, Vol. 46, No. 4, 2004, pp. 511-517. doi:10.1007/s00244-003-3042-5

[19] E. D. Clotfelter, L. J. Curren and C. E. Murphy, "Mate Choice and Spawing Success in the Fighting Fish Betta splendens: The Importance of Body Size, Display Behavior and Net Size," Ethology, Vol. 112, No. 12, 2006, pp. 1170-1178. doi:10.1111/j.1439-0310.2006.01281.x

[20] P. Verbeek, T. Iwamoto and N. Murakami, "Differences in Aggression between Wildtype and Domesticated Fighting Fish Are Context Dependent," Animal Behaviour, Vol. 73, No. 1, 2007, pp. 75-83. doi:10.1016/j.anbehav.2006.03.012

[21] I. G. Parsons, "The Effects of Fluoxetine on Aggressive Behaviors in Siamese Fighting Fish (Betta splendens)," A Report of a Senior Study, Maryville College Fall, 2005, p. 11.

[22] J. I. Johnsson and A. Akerman, "Watch and Learn: Preview of the Fighting Ability of Opponents Alters Contest Behaviour in Rainbow Trout," Animal Behaviour, Vol. 56, No. 3, 1998, pp. 771-776. doi:10.1006/anbe.1998.0824

[23] J. G. M. Dreksen, G. B. L. Rijs and R. H. Jongbloed, "Diffuse Pollution of Surface Water by Pharmaceutical Products," Water Science and Technology, Vol. 49, No. 3, 2004, pp. 213-221.

[24] B. W. Brooks, C. M. Foran, S. M. Richards, J. Weston, P. K. Turner, J. K. Stanley, K. R. Solomon, M. Slattery and T. W. LaPoint, "Aquatic Ecotoxicology of Fluoxetine," Toxicological Letters, Vol. 142, No. 3, 2003, pp. 169183. doi:10.1016/S0378-4274(03)00066-3 